\title{
EX-OFFENDER REINTEGRATION AND SUSTAINED PEACE IN THE NIGER DELTA REGION OF NIGERIA: ADOPTING A SOCIO-ECONOMIC CHANGE MODEL APPROACH
}

\author{
BENJAMIN A. UBLEBLE ${ }^{1}$, JOHN M. AGOMOH ${ }^{2}$, ANTHONY CHOVWEN ${ }^{3}$, \\ ${ }^{1}$ Centre for Conflict and Gender Studies, University of Port Harcourt, Nigeria \\ ${ }^{2}$ Department of Sociology, Eastern Palm University, Ogboko, Nigeria \\ ${ }^{3}$ Living Earth Nigeria, Port Harcourt \\ (C) 2019 Benjamin A. Ubleble, John M. Agomoh, Anthony Chovwen \\ This is an open access article distributed under the Creative Commons Attribution-NonCommercial-NoDerivs \\ license (http://creativecommons.org/licenses/by-nc-nd/3.0/) \\ DOI: $10.1515 /$ eras-2019-0005
}

\begin{abstract}
The Niger Delta of Nigeria rich in oil and gas resources has been plagued with series of armed conflicts characterised by massive youth restiveness. The peaceful coexistence of people in the region is often affected by the nature of oil and gas business determined by the political economy of the Nigerian state. By the statute of the Federal system of Government in Nigeria, all resources within the territorial boundary of the country belong to the Federal Government. The Government then pays a certain 13\% derivation fund to the resource bearing states for development. The Federal Government equally sees to the development of the region through its statutory Agencies such as the Niger Delta Development Commission. All these efforts are yet to bring about infrastructural development and human capacity needs of the region. A consequence of this is the armed militancy and cult related violence that has engulfed the region. In this paper, an attempt is made to analyse the socioeconomic requisitions of a reintegration programme for ex-offenders seeking re-entry into mainstream society. An interventionist approach is recommended with effective monitoring and evaluation system for a socioeconomic reintegration of ex-offenders in the Niger Delta region of Nigeria.
\end{abstract}

Keywords

Socioeconomic, Reintegration, Ex-offenders, Niger Delta.

\section{Introduction}

Rising tensions from oil and gas business coupled with the nature of politics in the Niger Delta region and Nigeria at large ensures that militancy and cultism supremely drive in the region. Various levels of militancy coupled with cultism in the Niger Delta have manifested in different forms of hostage taking, sea piracy, political hooliganism, terrorism and pipeline vandalism in widespread dimension in the region (Ojo, 2015). The Niger Delta has become known in most extant literatures for a form of "alienation caused by ethnicity based political domination, oil based environmental degradation, corruption and parental neglect...." (Ibaba, 2008). This trend over the years "...has engendered frustration and awareness that explain the conflicts and violence in the area" (Ibaba, 2008). Ethnicity based politics in the Niger Delta as presented in the argument by Ibaba are traceable to the political economy of the Nigerian state, where the Federal Government pockets the largest share of proceeds from the oil and gas resources extracted from the region. 
It is perceived that since the political class has been dominated by a particular section of the country, ownership of oil wells equally is dominated by those who control the politics. Such perceptions held largely by people, especially by militants, have in many instances fuelled resource control agitations. Feelings that the oil and gas resources from the region are controlled by cabals from the Northern part of the country have caused series of violent forms of agitation, which in many instances crippled the economic activities around the Niger Delta. Such arguments have stirred up violent agitations resulting in militancy and cult related violence. Ownership of oil wells for instance has been an issue of intense controversy in many public domains with many voicing out that individuals should not own oil wells in the first place in a Federal structure of Government. Akukwe(nd) argues that oil well ownership space in the Niger Delta is dominated by cabals related to the northern oligarchies of ex-military dictators in the ranks of Generals Babangida, Abacha, Abdulsalami among others.

A considerable percentage of the oil wells are owned by Northern oligarchies and other persons outside of the Niger Delta; the control of such national resources is by those who have dominated the politico-economic space in the history of the country. A quick look at the scene shows that oil wells are shared according to the whims and caprice of the Commander-in-Chief of the Federal Republic. Akukwe(nd) explains that the following people were awarded oil blocks, either due to consanguinity, political affiliations or a combination of these two factors. It does not have to do with anything close to merit or geospatial distribution of a beneficiary; it is an exclusivity of the Commander-in-Chief of the Federal Republic.

$>$ OML 110 run by Cavendish Petroleum is owned by Alhaji Mai Daribe, the Bornu Patriarch. The oil well was awarded by General Sani Abacha in 1996.

$>$ OPL 246 operated by Sepetro is owned by General Theophilus Danjuma and was awarded to him by General Sani Abacha.

> OML 112 and OML 117 operated by AMNI International Petroleum Development Company are owned by Col. Sani Bello since 1999 when it was awarded to him by General Abdusalami Abubakar. Ownership of some of its stocks is by Rilwan Lukman, a onetime OPEC Chairman.

$>$ OML 115, OLDWOK and EBOK fields run by Alhaji Mohammed Indimi were awarded to him by General Ibrahim Babangida who incidentally is his in-law.

$>$ OML 215 operated by Nor East Petroleum Limited is owned by Alhaji Saleh Mohammed Gambo.

$>$ OML 108 which is operated by Express Petroleum Company Limited is owned by Alhaji Aminu Dantata.

$>$ OML 113 owned by Yinka Folawiyo Pet Ltd is owned by Alhaji W.I. Folawiyo.

$>$ ASUOKP/UMUTU Marginl Oil Fields is operated by Seplat Petroleum, which is owned by Prince Nasiru Ado Bayero.

There is no need to delve further into the statistics of monetary valuations per barrel of oil accruing from ownership of these oil well deposits to the owners because its entirety is a thesis for another literature as a whole. But the argument in this is that substantial ownership of oil wells in the Niger Delta is controlled by people outside the geospatial area called Niger Delta region and this trend is blameworthy for armed confrontations and restiveness in the region. What is the implication of this scenario to sustain peace in the region?

Violent confrontation has a tendency of manifesting in various dimensions and may even invent other forms of interrelated criminal behaviours. For instance, kidnapping done with the aid of a weapon to intimidate and subdue the victim may end up in a murder case just in the same way as the use of weapons to subdue a victim in a rape attempt may end up in injurious act culpable for murder. In any of these classic cases, there may not have been any intension to hurt the victim, but in a situation of resistance anything could be possible. Two 
things stand out here: the use of force to subdue the victim and the aftermath of that force. It is resistance from the victim that eventually leads to harm in form of murder. In application, it thus entails that the thievery and expropriation of people of the Niger Delta from the oil and gas resources, land, water and all accompanying resources in the political economy of Nigeria have caused the resistance in form of violent agitations. These violent agitations have both manifest and latent consequences in the form of pipeline vandalism, oil theft and artisanal refining, as well as forms of environmental degradation, kidnapping, hostage taking, cultism and militancy, that is rampant in the Niger Delta.

It is an open secret that resource control agitation came about, as one of the means to seeking redress from the Federal Government. The same explanation suffices for militancy and hostage taking. During General Obasanjo's administration which started in 1999, such agitations were rebuffed by his government and they eventually became the precursors of violent conflicts which crippled his Government prior to the amnesty programme for exmilitants initiated by the succeeding administration of Alhaji Umar Musa Yar'Adua. Issues of Government backed thievery of the military class, massive corruption in the petroleum sector, huge briberies and bootlicking in the political space ensured that oil wells were distributed at the slightest favours done to any of the Head of states that have ruled Nigeria in the past. The process was even demonised during the military era as Akukwe(nd) encapsulate in the following text.

"The process of sharing Nigeria's oil block national cake is as fraudulent now as when Ibrahim Babangida started the process of discretionary allocation of oil blocks to indigenous firms. Discretionary allocation of oil blocks entails that a president can reward a mistress who performs wonderfully with an oil block with capacity for cumulative yield of over $\$ 20$ billion dollars without recourse to any process outside of manhood attachments. Babangida, Abacha, Abdulsalami and Obasanjo awarded discretionary oil blocks to friends, associates, family members, party chieftains, security chiefs and all categories of bootlickers, spokespersons and cult members without any laid down procedures. The recipients of such oil blocks will get funds from ever willing offshore financiers and partners to graciously settle the benefactors, the awarders, facilitators and the Commander-in-Chief through fronts. These settlements mostly paid into foreign accounts runs into hundreds of millions of dollars according to the potential yield of the block".

The abuse of executive powers in the resource governance not minding that the Niger Delta is home to about 20 million people of various tribes ensures that the region remain enormously fragile with heavy hydrocarbon pollution which has unquantifiable impact on both the environment and livelihoods of people in the area (Ubleble \& Gbenemene, 2017). The Federal Government has responded in a number of ways to address this challenge with very little to show for the huge budget expended in the area. One of such projects is the implementation of the Amnesty Programme for the repentant militants. The Federal Government during the administration of Alhaji Umar Musa Yar'Adua introduced the Amnesty Programme for Ex-militants to cushion the effect of violent conflicts which had crippled oil and gas production near zero level in the wake of his administration. However, implementation of the Amnesty Programme which was to rehabilitate, reconcile and reintegrate beneficiaries into mainstream society failed to reduce violent conflicts in the region. An indicator of such failure is the inability to attract substantial direct foreign investment into the region and the continued retrogression in oil and gas economic activities 
as a whole.

The inability of the Federal Government in "addressing the genuine needs of the people of the region through good governance at the various levels of Government, provision of essential social infrastructures as well as strict adherence to international environmental standards by the oil companies" have put the region in a state of perpetual retrogression among international committee of nations (Nwogwugwu et al., 2012). This situation has led to collective frustration with renewed militancy in the region. The opinion of Nwogwugwu et al. (2012) in above is a macro analytic issue. However, current disclosure on the politics of resource control in the Niger Delta has unveiled deeper micro analytic issues implicated in the renewed spirit of militancy in the region.

Firstly, "ex-militants preferred to remain enrolled in the amnesty programme, instead of switching to lower-paying jobs in their communities. Secondly, they started attracting new youths into militancy. Evidence shows that youths who were not part of any armed militant group started to mobilise into new groups or join existing ones in order to benefit from the amnesty programme. In some instances, they quickly purchased weapons from the black market to enable them to participate in the programme" (Tarila \& Arnim, 2017).

Militancy is fast becoming a lucrative trade. It is a trade in that the failure of the Amnesty Programme has instead of solving the problem of militancy created a new social class because it has been manipulated by powerful political gladiators for parochial minded intentions. The Federal Government's pledge to end militancy in the Niger Delta has been more of institutional response targeted at disarmament, demobilization, rehabilitation and reintegration assistance. In doing this, key activities aimed at transferring knowledge and skills to the ex-offenders, acquisition of industry skills, financial empowerment schemes, placement programmes, micro-credit and educational programmes were structured for target beneficiaries. More so, reconciliation with local community, conflict resolution mechanism, monitoring and evaluation and exit strategies from the amnesty was planned for the militants in the region (http://www.osapnd.gov.ng/index/ndap). For the reasons that militancy and cultism are still a serious issue in the Niger Delta, despite huge budgetary spending by the Federal Government and some state Governments, points to the fact that there is need for a paradigm shift from the reintegration model adopted by the Amnesty Office of the Federal Government. A more integrated, sustainable and strength based reintegration model must be contemplated targeting community level reintegration strategy.

A socioeconomic programme designed to target individual specific ex-offender issues and challenges is proffered in this study. No two ex-offenders would require exactly the same treatment with exceptions of localised case studies. The experiment of a Generalised Treatment Model implemented by the Amnesty Office has showed significant weaknesses resulting in increased rates of re-offending and admittance of new entrants into the clique. In this case, a Strength Based Strategy with defined tendency of reduction in rates of reoffending behaviour is proposed. Strength Based Programmes take cognisance of both personal and community assets among reformed ex-offenders before reintegration and elsewhere, the strategy has shown successful reintegration into community life where it was experimented (Maruna \& LeBel, 2002). In going further with Strength Based Treatment process, there must be de-emphasis in the payment of monthly stipends to beneficiaries, because this is where the failure of the Amnesty Office of the Federal Government started to weigh in since it only succeeded in making the programme robust enough to accommodate new entrants into militancy.

\section{Materials and Methods}

Materials for the study came from qualitative sources only. Qualitative data from peer 
review journals, internet sources, books, magazines as well as news paper publications were sourced to derive information for this paper. Materials were collected from observatory participation during field trips, through interviews and community engagements in parts of Rivers, Bayelsa and Delta states. Obtained data were analysed, then used to determine the Strength Based reintegration strategy proposed in this study. A social assessment was undertaken at the Rivers State Amnesty Programme Office for repentant cultists and substantial data sourced from the office represent part of the generated data obtained from the process. The process described above produced the informed opinion which is presented as result of the study. Such informed opinion established the general precepts in the logic upon which the conclusion is drawn.

\section{Results}

In an attempt to successfully reintegrate an ex-offender in the Niger Delta of Nigeria, lifestyle attributes of such ex-offender must be carefully profiled. Wrong or inaccurate profiling and diagnosis in each case will portend a wrongful result. Therefore, the result presented here takes cognisance of singularity of the treatment programme. In the socioeconomic reintegration model, ex-offenders are profiled in line with the proposed Strength Based Strategy, noting a chain of activities needed to transform recipients into socially beneficial individuals in the society. Socially beneficial individuals are those who successfully go through a reintegration programme, with limited chances of re-offending. According to Lopex et al. (2015), the very foundation for citizenship reintegration is to bridge the gap in the social relations between excluded members and mainstream society through building of social cohesion along the lines where disintegration had taken place. Series of activities are involved in the bridge building process of reintegration. Though there is no uniformly applicable model of reintegration, the case of the Niger Delta shows a likelihood of socioeconomic related solutions

\section{Socioeconomic Reintegration}

Approaching reintegration of ex-offenders generally requires series of actions to be initiated at various levels. In this case, those actions will be analysed using a change model solution displayed in a theory of change. This will better represent the scenario bearing in mind that it explains the process of change by showing the causal linkages in an intervention indicating short term, midterm and long term outcomes (Clark \& Taplin, 2015). Micro level change models clearly state various stages of transformation which individual ex-offenders necessarily undergo in the reintegration programme. As Danielle \& Valter (2012) aptly put it, "changing individuals involves strategies that shift attitudes and perceptions, feelings, behaviours and motivations of participants in an intervention".

In the reintegration change model shown in figure 1 below, a prediction path is displayed showing the result chain channel for ex-offenders at different intervention levels. These intervention levels generally are categorised into input, activities, output and outcome channels. The input channel has six classified properties stated as resources, in this case both human and material, including the requisite technical support required at this stage. Equally, at the input stage, a specialised form of training is developed in a well-articulated manual with details on subject areas most beneficial to the beneficiaries. Most importantly, the beneficiaries being ex-militants, cultists and all combatants require specialised trainings from Consultants, Technocrats and Skilled Trainers to instil the culture of discipline, selfperception, emotional intelligence, impression management and entrepreneurship. In every case, energy will be dissipated on psychosocial profiling prior to socioeconomic empowerment. It is at this stage that basic aptitude of each beneficiary is identified. The input 
stage goes further to tell about the services of critical partners such as Military, Paramilitary and Faith Based Support Services, as may be applicable in each individual case.

The second channel in this quartet deals with series of activities designed to accelerate community re-entry. The first in this order is the need assessment study. The idea of a need assessment study in this case is to prioritise existing opportunities available to beneficiaries at mainstream societal level. The need assessment study ordinarily paves the way for community entry point activities. These activities may connote community level dialogues, family reconciliation talks and declaration of intention to reconcile and reintegrate target beneficiaries. At this level, community support frameworks are usually established to facilitate social cohesion. Social cohesion activities may take place at family and community levels with reunion meetings, sports festivals, community service projects among others. These may be initiated based on findings from the needs assessment report. What follows in this order is the skill transfer from ex-offenders to community volunteers. This is a peace initiative aimed at confidence building in the reintegration goal.

At the output level, the reintegration change model expectedly begins to show early signs of social inclusion of ex-offenders into mainstream community. This is because the community reconciliation and reintegration machinery put in motion in form of socioeconomic starter packs in areas of identified opportunities through quick impact projects takes a stronghold at mainstream society. Again, capacity generation in profiled skilled areas transferred to community volunteers firmly registers a strong presence at mainstream society through demonstration of creativity. The societies where these actions are initiated begin to have a change of orientation towards the ex-offenders and gradually the ex-offender status begins to disappear as a result of the positive aura that radiates around the transformed exoffenders in the society.

The outcome level is a long term evaluation point where the progress of the reintegration programme is eventually validated. Some outcome may be immediate, such as the change in perception about the ex-offender status of beneficiaries. Again, as the programme gains wider societal acceptance, the tendency for midterm and end-term outcomes become more realistic. However, some of the outcomes generally may begin to manifest in the form of settled lifestyle of reformed ex-offenders. A typical example of this could mean that some of the beneficiaries will begin to demonstrate high level mastery of their socioeconomic independence through the initiated quick impact projects. At such point, social cohesion must have been achieved since the immediate community will be the primary markets patronising the socioeconomic activities of the beneficiaries. So this patronage is what will eventually guarantee a situation of full reintegration of the ex-offenders both at family and community levels on the long run. 


\section{Figure 1: Socioeconomic Reintegration Change Model for Ex-Offenders Source: Ubleble \& Agomoh, 2017}

Input Activities Output Outcome

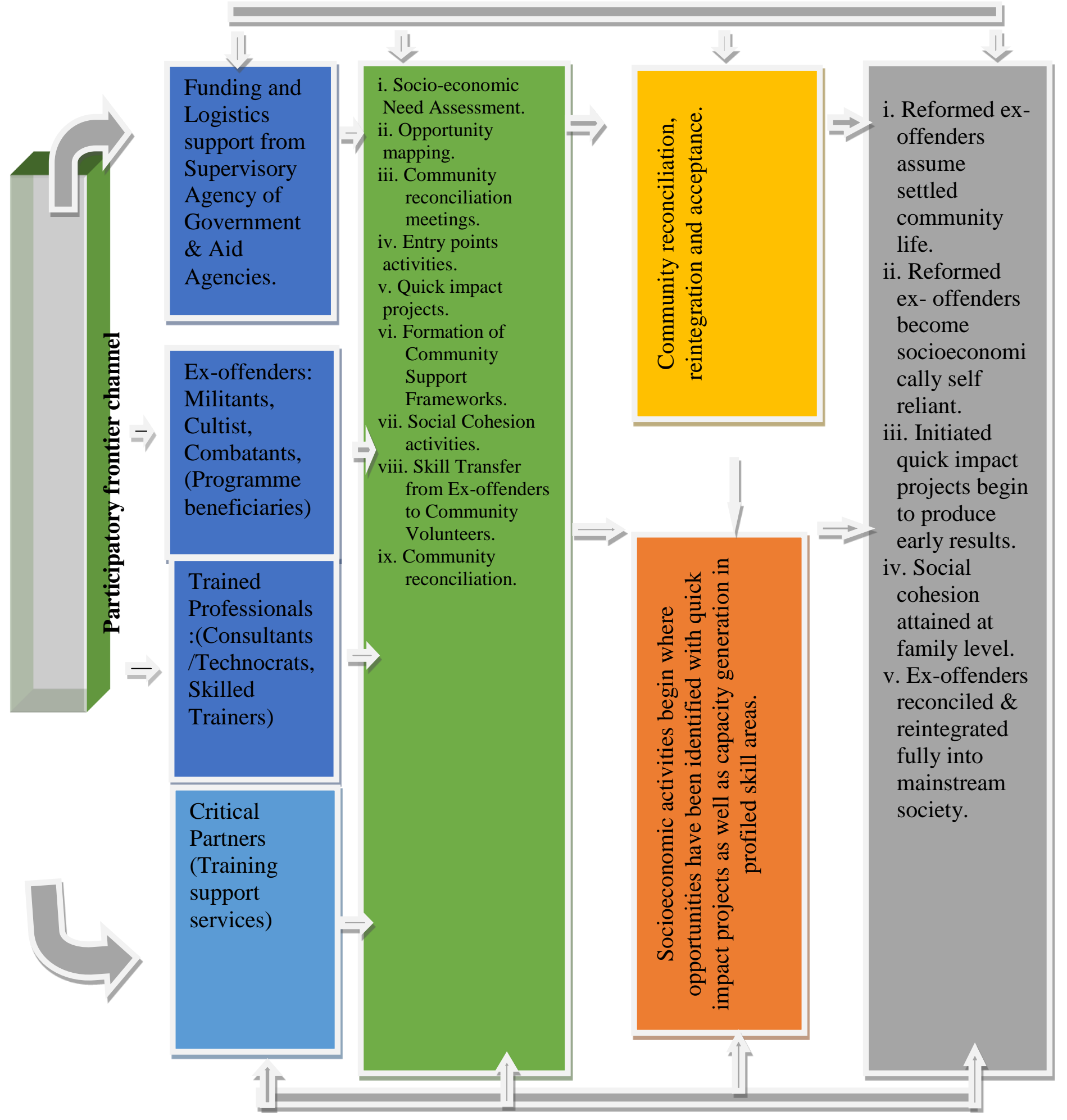




\section{Discussion}

As presented from the onset, the structure of the political economy of Nigeria has created tendencies with possibilities of inciting violent agitations. Ojochenemi et al. (2015) after a thorough analysis of the political economy of Nigeria arrived at a conclusion that inherent tendencies of lack of accountability and systemic corruption in the resource governance space have fuelled terrorism crimes against the state. Terrorism in this case is purely targeted at large scale destruction of oil and gas installations with unquantifiable impact on the environment and livelihoods. This form of terrorism is called eco-terrorism and it emanates from the collective frustration of the owners of the resources who have been expropriated from it.

The version of federalism practised in Nigeria, which gives too much control to the centre, and in this case where the resources found anywhere within the territorial boundaries of the country are exclusively controlled by the federal government, is faulty. The resistance which started in form of resource control agitations soon became too powerful for the Nigerian state to contend. It goes further to suggest that the act of terrorism against the environment is a form of resource control agitation. The resultant criminality from it has completely exposed the failure of governance in the Niger Delta. This has been exacerbated by the increase awareness of people in the region about modern forms of resistance which include oil theft, artisanal refining and vandalism of infrastructures in an attempt to take control of abundant oil and gas resources in the region. There are other forms of criminality flourishing as offshoot from this trend in form of hostage taking, kidnapping, cultism as well as other forms of organised crimes. The citizenry is well aware of the responsibility of Government in the delivery of certain expectations, and when there is failure in doing so it is always accompanied by resistance. Where such conditions exist in a democracy and the pursuit of genuine sustainable economic prosperity is subverted by the state and its agents, the attendant consequence of it will be the unsettling of the state (Adewale, 2011). The Niger Delta crisis of violent agitation is a ploy by militants, cultists and all combatants to unsettle the Nigerian state.

Series of attempts have been made both by the Federal Government and some state Governments to restore peace to the Niger Delta through rehabilitation, reconciliation and reintegration programmes with very little to show. This informed the proposition of a Strength Based Approach advocated here for the reintegration of ex-offenders in the Niger Delta. The earlier attempts of Government at all levels in the rehabilitation, reconciliation and reintegration of ex-offenders was either over politicised or inadequately implemented, that is why it is imperative to delve deeper into a Strength Based Approach as presented in this study. Its advantage is that it goes beyond the known values to the imperceptible micro and macro levels of analyses targeting psychological, social and economic characteristics of the ex-offenders and mainstream society where reintegration is proposed. As such, it takes cognisance of pre and post psychosocial and economic requisitions of a successful reintegration programme in the Niger Delta.

The literature is awash with Strength Based Strategies for reintegration programme. However, the strategy developed in this study provides the pre and post conditions with activities that will accelerate a successful reintegration attempt in the Niger Delta. According to Hunter et al. (2017), strength based methodology to offender reintegration identifies the assets and build on those assets effectively to derive desired results. Saleeby (1996) considers that such a situation provides the right momentum in dealing with pre-conditions, qualities and attributes that can reliably inform on how to go about achieving set objectives of a reentry programme wherever it is applied. Strength Based Approaches considers both the individual and community very useful in planning a reintegration programme. It considers 
talents, skills, knowledge, as well as potentials of an individual and the community at large as value addition to the intended reintegration programme (Pattoni, 2012).

\section{Conclusion}

The result chain process of the reintegration model presented in figure 1 above exemplifies how pre and post conditions for an ex-offender reintegration programme works. At the input channels, attention is devoted to getting the right resources and technical support and all pre conditions in place. The second phase, which is the activity section, deals with part of the pre-conditions, especially in undertaking a needs assessment study and opportunity mapping. Some activities under here could qualify as midline conditions, such as social cohesion activities and skill transfer which is vital for sustaining community level reintegration. At the output channels, lower expectations begin to emerge giving signs of a successful reintegration programme with the running of socioeconomic activities and quick impact projects. The outcome stage is a stage where higher outcomes begin to manifest with the ex-offender status disappearing with the full reintegration of the beneficiary into full family and community life. The reintegration of ex-offenders in the Niger Delta requires a localised programme taking into consideration issues of cultural diversity and individual differences which have been missing in all previous rehabilitation, reconciliation and reintegration attempts of Governments at all levels.

\section{REFERENCES}

Adewale, A.R. (2011) The Political, Economic and Social Dynamics of Nigeria: A Synopsis. African Institute of South Arica. (39) pp 1-8

Akukwe, O. (nd). 20 Owners of Richest Oil Blocks in Nigeria- Their Names Will Shock You. Available on line at facesinternationalmagazine.org.ng/?p=2533

Clark, H. \& Taplin, D. (2012) Theory of Change Basics: A Primer on Theory of Change. Available at http://www.theoryofchange.org/wp-content/upload/toco_library/pdf/ToCBasics.pdf

Danielle, S. \& Craig V. (2012). Understanding Theory of Change in International Development. Journal of Social Research and Policy, Paper 1.

Hunter, B.A, Lanz, A.S., Lawlor, M., Dyson, W. A \& Gordon, D. (2017) A Strength-Based Approach to Prisoner Reentry: The Fresh Start Prisoner Reentry Programm. Available online https://www.ncbi.nlln.nih.gov/pmc/articles/PMC4580511/

Ibaba, S. I. (2008). Alienation and Militancy in the Niger Delta: Hostage Taking and the Dilemma of the Nigerian State. African Journal on Conflict Resolution. (8) 2

Lopex, M.R., Andreauli, E. \& Howarth (2015) Special Thematic Session "The Social Psychology of Citizenship, Participation and Social Exclusion". From Ex-combatants to Citizens: Connecting Everyday Citizenship and Social Reintegration in Colombia. Available online at oro.open.acul/43945/1/388-3031-3-PB.pdf

Maruna, s. \& LeBel, T. (2002). Revisiting Ex-Prisoner Re-entry: A Buzzword in Search of a Narrative Cited in Rex, S. and Tonry, M. (eds), Reform and Punishment: The Future of Sentencing, Portland: William Publishing, pp 158-180

Nwogwugwu N., Alao, O.E \& Egwuonwu, C. (2012). Militancy and Insecurity in the Niger Delta: Impact on the Inflow of Foreign Direct Investment in Nigeria. Kuwait Chapter of Arabian Journal of Business and Management Review. (2), 2

Ojochenemi, J.D., Asuelime, L.E \& Onapajo, H. (2015) Political Economy of Nigeria. Available online at https://link.springer.com/chapter/10/1007/978-3-319-21230_3

Ojo, M. O. (2015). Militia Uprising in the Niger Delta and its Implication for National Security. International Journal of Development and Sustainability 4 (9) pp 919-939

Pattoni, L. (2012) Strength-Based Approaches for Working with Individuals. Available online at https://www.iriss.org.uk/resources/insights/strengths-based-approaches-working-individuas

Saleeby, D. (1996) The Strenghts Perspective in Socal Work Practice: Extensions and Cautions. Social Work (41) pp 296-305

Tarila, M.E \& Arnim, L. (2017). How Amnesty Efforts in the Niger Delta Triggered New Violence. Available online at from reliefwebnet/report/Nigeria/howamnestyeffortsinthenige 
Benjamin A. Ubleble, John M. Agomoh, Anthony Chovwen, Ex-offender reintegration and sustained peace in the Niger Delta region of Nigeria

DOI: 10.1515/eras-2019-0005

erdeltatriggerednewviolence

Ubleble, B.A \& Agomoh, M. John. (2017). Concept Note on Ex-Militants' Reintegration Programme in the Niger Delta Region of Nigeria. Notes submitted to NOSDRA, Abuja.

Ubleble, B.A \& Gbenemene, K. (2017). Cognitive Development in Children and Environmental Leadership Project for Sustainable Development in the Niger Delta Region of Nigeria. International Journal of Innovative Psychology and Social Development. 5 (4) pp 21-33 